\title{
On-Farm Demonstration of Improved Rice (Oryza sativa L) Varieties in Pawe District of Benshangul Gumuz Regional State, Ethiopia
}

\author{
Fistum Miruts \\ Ethiopian Institute of Agricultural Research, Melkassa Agricultural Research Center
}

\begin{abstract}
Four varieties (Hidasie, Nerica-12, Nerica-4 and Pawe-1) were demonstrated and evaluated on a farmer's field. Average yield performances of the demonstrated varieties show 42.66, 34.19, 33.41 and 32.23 quintal per hectare of Pawe-1, Nerica-3, Hidasie and Nerica-12 varieties respectively. Pawe-1 variety showed better yield performance. In the ranking, Pawe-1 was selected as the best-preferred. Based on farmers' perception, Pawe-1 was ranked first as it produces a good yield, high tilling capacity, the white colour of the grain and preferred at the market with good price. This result indicates Pawe-1 variety is farmers' best preferred and top performed variety which can be considered as a promising variety to be widely produced by rice farmers in the study area. The yield under demonstration plots was higher than the local cultivar and the use of research recommended rice cultivation method can reduce the technology gap to a considerable extent. Therefore, it is recommended that the office of agriculture of the District needs further scale up the varieties to other areas to benefit quite a significant number of farmers.
\end{abstract}

Keywords: Demonstration, Evaluation, Pawe, Rice

DOI: $10.7176 / \mathrm{JNSR} / 10-7-03$

Publication date: April $30^{\text {th }} 2020$

\section{Introduction}

In Ethiopia, agriculture is the leading sector which contributes to nearly $34.9 \%$ of GDP It also serves as the main source of food and generates $88.8 \%$ of the foreign exchange earnings. Crop productions contribute the lion share to the Ethiopia's agriculture and economy (NBE, 2018). About $80.6 \%$ of the total population live in rural areas and earn their livelihood from agriculture. Nearly $55 \%$ of all smallholder farmers operate on one hectare or less (MoARD, 2010).

From the total cultivated area, a larger area (90\%) is covered by grain crops (cereals, pulses, and oilseeds). Within the category of grain crops, cereals are the major food crops both in terms of the area they are planted and volume of production obtained. They are produced in larger volume compared with other crops because they are the principal staple crops (CSA, 2018).

In Ethiopia, Maize, tef, wheat and sorghum are among the cereal crops used to be the staple food crops and target of most of the food security programs. However, the recent trends in the area and production of rice along with its high compatibility in the traditional consumption habits shows that rice is becoming one of the staple foods and important for ensuring household food security (Mekonen, 2017). The rice expansion is associated with the possibility of producing it in marginal areas mainly in the abundant vertisols, the relatively high level of productivity achieved as compared to the main staple crop, tef, and the possibility of using in the traditional "enjera" making (Teshome and Dawit, 2011).

Rice was introduced in the 1970s and since has been cultivated in different parts of the country (MoARD, 2010). Although rice has just been recently introduced to Ethiopia, recognizing its importance as a food security crop and a source of income, and employment opportunities, the government of Ethiopia has named it the "millennium crop," and has ranked it among the priority commodities of the country (Teshome and Dawit, 2011).

Ethiopia has a huge potential for rice production especially, in the area of the Gambella region, the Fogera plain around Lake Tana and Benishangul Gumuz Regional state. The potential rain-fed rice production area in Ethiopia is estimated to be about thirty million hectares (Tamirat and Jember, 2017).

According to the report from CSA, the area covered by rice during 2007 was 24,434 hectares and elevated to nearly 53,106 hectares in 2017 and the production from 713,160 quintals to 1,510, 183 quintals. At the same time, the number of rice farmers increased from 61,862 to more than 161,376 (CSA, 2007;2018). Even though the production and area coverage increased the productivity of the crop is very low ( 28 quintals per hectare) compared to the global average (CSA, 2018).

In Pawe District, the crop was introduced in 1985 during the resettlement program and establishment of Pawe agricultural research center (Dawit et al., 2018). Currently, the District is one of the rice-producing areas, and it is considered as the major crop and cultivated by smallholder farmers for household consumption (injera, bread and alcoholic drinks). It is also used as a cash crop, source of feed, and house construction material (Teshome and Dawit, 2011). 


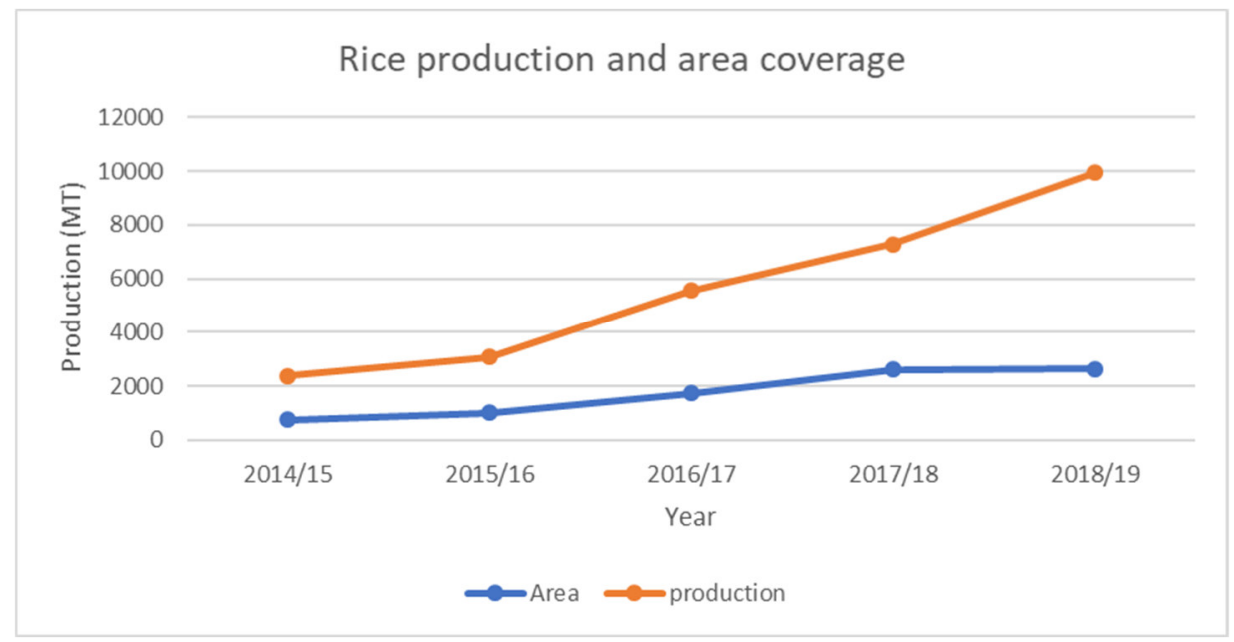

Figure 1:. Trend in rice production and area coverage in Pawe District

Source: PDoA (2014/15 - 2018/19)

According to the report of Pawe district agricultural office (PDoA, 2014/15-2018/19), the total land used for rice production and total yield over the period is increasing. This shows even if the rice has been recently introduced to the area, recognizing its importance as a food security crop and a source of income, the area coverage and production increasing but the productivity is low compared with the potentials of research released varieties for the study area.

Pawe agricultural research center in collaboration to other sister research centers adapted and released several high-yielding and disease-resistant rice varieties together with their associated improved agronomic practices (EIAR, 2016). Demonstration and evaluation of these varieties in the farmers' field are vital, to promote the newly released varieties and evaluate them under farmers condition. Seed replacement with improved varieties is also an important tool to enhance the productivity of rice growers (Yalamalle and Tomer, 2019). Hence, with these in view, the study was carried out to show the performance of recently released rice varieties with their agronomic recommendations and select and recommend the best-fit variety based on farmer's selection criteria for future technology scaling-ups.

\section{Materials and Methods}

\subsection{Description of the Study Area}

The demonstration was conducted in Pawe district which is one of the districts in the Benishangul Gumuz regional State (Figure 1). It is located geographically between $36^{\circ} 20^{\prime}-36^{\circ} 32^{\prime}$ longitude and $11^{\circ} 12^{\prime}-11^{\circ} 21^{\prime}$ latitude with an altitude of 1120 mean average see level. The district has 20 kebeles and the climate of the area is hot humid and characterized by unimodal rainfall pattern with high and torrential rainfall that exceeds from May to October. The area experiences a temperature ranging from $19.4^{\circ} \mathrm{C}$ to $37.6^{\circ} \mathrm{C}$ with a mean annual rainfall of $1586 \mathrm{~mm}$. The district covers a total area of 63,400 hectares. The farming system of the district is characterized by a mixed croplivestock farming system dominated by crop production. The major crops grown in the district include; maize, finger millet, soybean, sesame, groundnut and rice (PDoA, 2018). 


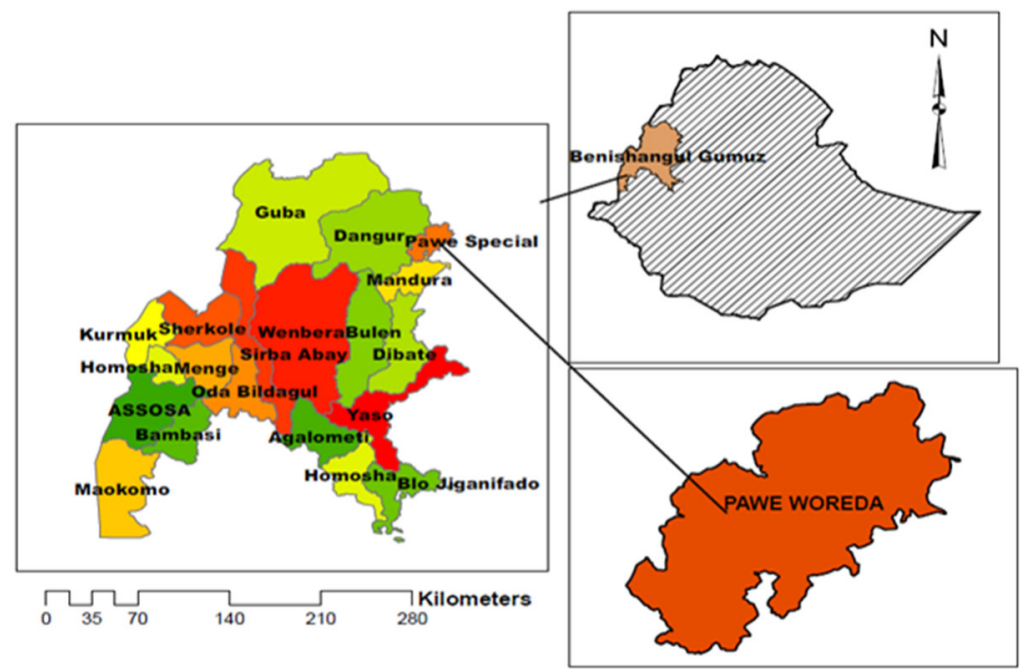

Figure 2: Location of the study area

\subsection{Farmers Selection and Field Establishment}

In consultation with district agricultural experts, farmers who have an interest in the technology, willingness to manage and allocate field for the demonstration and willingness to collaborate with extension agents and researchers were selected for hosting the demonstration. Twenty farmers were selected and the demonstrations were established in a farmer's field were each farmer considered as a replication. For the demonstration, full technology packages of rice were provided. The varieties were planted in 0.25 hectares in each demonstration host farmers' field. Hidasie, Pawe-1, Nerica-12, and Nerica-3 varieties that have been released from the research were grown side by side to demonstrate and compare their performance with the one that farmers are using (local cultivar). Before the establishment of the demonstration or planting the seeds, both practical and theoretical training was provided on the improved rice technology from production to marketing.

In the demonstration plots, farmers used a row spacing of $20 \mathrm{~cm}$ within rows and $15-20 \mathrm{~cm}$ space between plants and $80 \mathrm{~kg} /$ ha seed rate. Fertilizer application, insect pest control, and other necessary practices were applied as per the rice production package (EIAR, 2016). The date of planting was maintained the same for all varieties. Follow-ups and essential advice from respective researchers and agricultural experts have been given to demonstration host farmers. During each visit, discussions were made with the farmers and DAs right on the demonstration plot to jointly evaluate the performance of the varieties on the field. During the visit, both farmer's and development agent's data recording format were checked to observe how they handled the information gathering process.

\subsection{Data Collection and Analysis}

The activity data were collected by the researchers directly from the field. Farmer's perception of the varieties was recorded from focus group discussion during the evaluation process. The collected data were analyzed using descriptive statistics and preference ranking based on farmers' set criteria. Finally, the extension gap, technology gap, technology index along with the benefit-cost ratio were worked out. The technology gap shows the gap in the demonstration yield over potential yield. The observed technology gap is attributed to dissimilarities in soil fertility, salinity and erratic rainfall and another variability of weather conditions and used to provide location-specific recommendations (Samui et al., 2000).

Technology Gap = Potential yield - Demonstration yield

Extension Gap = Demonstration yield - Farmer yield

\section{Result and Discussion}

\subsection{Training of farmers and other stakeholders}

Training on rice production and management practices were given to demonstration host farmers (twenty) and development agents (four) who were working in the study site. This includes both theoretical and practical types of training. During regular visits, there were gaps identified by researchers. To fill the observed gap, field-level training was given by organizing farmers into small groups.

\subsection{Yield Performance}

For the study period from demonstration plots, yield data were collected from twenty farmer's field. Grain yield comparison between improved varieties (Hidasie, Nerica-12, Nerica-3 and Pawe-1) and local cultivar was made. 
The result obtained from the demonstration in the study area is described in Table 1.

As it is described in Table 1, average grain yield of 33.41, 32.23, 34.19 and 42.66 quintals per hectare were obtained from the improved rice varieties Hidasie, Nerica-12, Nerica-3 and Pawe-1 respectively, while the average grain yield of local cultivar was 28 quintal per hectare. This implies, the research released varieties gave a higher yield than the local cultivar in the study area. Similar yield results were also obtained by Hailegebriel et al., (2017) which was about $34.30 \mathrm{qt} /$ ha for Hidassie, $35.73 \mathrm{qt} / \mathrm{ha}$ for Nerica-12 and $35.17 \mathrm{qt} / \mathrm{ha}$ for Nerica-3 variety in Tselemt district of Tigray regional state. The result also conforms with (EIAR, 2016) and suggests the positive effects of demonstrations over the existing farmers practice towards enhancing the yield of rice with its positive effect on yield attributes.

Table 1: Grain yield performance of rice varieties in farmers field (Qt/ha)

\begin{tabular}{lcccc}
\hline Varieties & Min & Max & Mean & SD \\
\hline Hidasie & 24.32 & 38.24 & 33.41 & 7.10 \\
Nerica-12 & 17.6 & 37.92 & 32.23 & 10.50 \\
Nerica-3 & 16.8 & 37.44 & 34.19 & 11.10 \\
Pawe-1 & 19.36 & 40.16 & 42.66 & 12.80 \\
Local cultivar & - & - & 28.00 & - \\
\hline
\end{tabular}

\subsection{Yield gap and Advantage}

The highest yield increment (14.66 qt/ha) was recorded by Pawe-1 variety of a $52.36 \%$ yield advantage over the local cultivar. Comparing with the local cultivar, all varieties have a yield advantage and yield increments; Hidasie (5.41 qt/ha) and, Nerica-12 (4.23 qt/ha) and Nerica-3 (6.19 qt/ha). This result was in consistent to those of Wubale et al., (2019) and Alemayehu (2017) who observed similar grain yield difference among the improved varieties of rice.

The difference in yield between the demonstrations and potential yields of the varieties was also well noted (Table-2). The technology gap showed the difference between demonstration yields and potential yield. The highest gap was found in Nerica-3 variety (10.81 qt/ha) and the minimum difference found with Pawe-1 variety (2.34 qt/ha). The difference in the yield result from the demonstration field confirms the productivity of rice varieties registration (EIAR, 2016). The technology gap could also be because of varying soil fertility, rainfall and unpredictable weather conditions. Generally, the varieties demonstrated yielded better to that of the control/ farmers practice. From the demonstration result, it can be concluded that the adoption of high yielding improved varieties can result in improved productivity and food security.

Table 2: Productivity, technology gap and extension gap in rice under on farm demonstration

\begin{tabular}{lccccccc}
\hline Varieties & $\begin{array}{c}\text { Yield* } \\
\text { potential }\end{array}$ & $\begin{array}{c}\text { Demo. } \\
\text { Yield }\end{array}$ & $\begin{array}{c}\text { Control } \\
\text { Yield }\end{array}$ & $\begin{array}{c}\text { Yield } \\
\text { increment }\end{array}$ & $\begin{array}{c}\text { \% increase } \\
\text { over control }\end{array}$ & $\begin{array}{c}\text { Technology } \\
\text { gap (qt/ha) }\end{array}$ & $\begin{array}{c}\text { Ext. gap } \\
\text { (qt/ha) }\end{array}$ \\
\hline Pawe-1 & 45 & 42.66 & 28 & 14.66 & 52.36 & 2.34 & 14.66 \\
Nerica- & & & & & & & \\
12 & 41 & 32.23 & 28 & 4.23 & 15.11 & 8.77 & 4.23 \\
Nerica-3 & 45 & 34.19 & 28 & 6.19 & 22.11 & 10.81 & 6.19 \\
Hidase & 42 & 33.41 & 28 & 5.41 & 19.32 & 8.59 & 5.41 \\
\hline
\end{tabular}

\subsection{Rice farmers considered varietal traits and ranking}

Farmers have their preference criteria to accept and use a specific variety or technology (Semagn et al., 2017). The finding of this study suggests that farmers in the area seek specific varietal traits, such as yield potential, tolerance to diseases better price and color. The farmers' perceptions of improved rice varieties specific characteristics significantly limit the acceptance and decisions to use the specific technology (Hailemariam, 2016). Therefore, the research centers have to give more attention to participatory research which considers farmers' priorities and needs.

Overall varietal traits and farmers preference of rice varieties categorized largely in terms of grain color, grain yield, marketability, pest/ disease resistance, maturity, bio-mass as discussed briefly below. The varieties were evaluated at crop maturity stage by a group of rice grower farmers. During preference ranking, selected farmers were asked to set their priority selection criteria. Selection criteria of farmers in the study area were based on an extensive discussion and agreement. The criteria were; Marketability, grain yield, grain color, seed size, maturity and tilling capacity.

Farmers who can represent the kebeles and who have long experience in rice farming were selected and participated in the evaluation of the demonstration plots/ varieties. In the preference ranking, Pawe-1 was the bestpreferred variety than the others in the demonstration. 
Table 3: Farmers preference ranking of the rice varieties

\begin{tabular}{lcccccccc}
\hline Varieties & $\begin{array}{c}\text { Market } \\
\text { ability }\end{array}$ & $\begin{array}{c}\text { Grain } \\
\text { Yield }\end{array}$ & $\begin{array}{c}\text { Grain } \\
\text { color }\end{array}$ & Seed size & Maturity & $\begin{array}{c}\text { Tilling } \\
\text { capacity }\end{array}$ & T. Score & Rank \\
\hline Pawe -1 & 4 & 4 & 4 & 3 & 4 & 4 & 23 & 1 st \\
Hidasie & 2 & 2 & 3 & 1 & 3 & 3 & 14 & 2 nd \\
Nerica -12 & 1 & 1 & 1 & 4 & 2 & 2 & 11 & 4 rd \\
Nerica -3 & 3 & 3 & 2 & 2 & 1 & 1 & 12 & 3 th \\
\hline
\end{tabular}

NB: preference ranking scale 1-4 (4= highest score/preferred and 1= lowest score/preferred)

As indicated in the Table 3, Pawe-1 is farmers' best preferred and top performed variety which can be considered as a promising variety to be widely produced by rice farmers in the study area. Based on farmers' perception, Pawe-1 variety was ranked first as it produces a good yield, white grain color, preferred at the market with good price. Farmers also reported that during the focus group discussion, Nerica-3 variety was early maturing but susceptible to bird attack in addition to the lower yield potential. It may be important to note at this point that proper practices are also potential factors for differences in yield (Table 3 ).

\section{Conclusion and Recommendations}

From the findings of this research, it was observed that there was a difference among the varieties used for the demonstration in the study area. Hence, Pawe-1 was found as the best rice variety as it produces a higher yield than Nerica-3, Nerica-12 and Hidasie varieties. Similarly, farmers also show their preference to Pawe-1 and Hidasie than Nerica-12 and Nerica-3 varieties based on good yield, white grain colour, preference at the market places in addition to its productivity. The yield under demonstration plots was higher than the local cultivar and reduce the technology gap to a considerable extent. Therefore, it is recommended that the office of agriculture of the district needs further scale up the varieties to other areas to benefit quite a significant number of farmers.

\section{Acknowledgement}

The financial support of the Ethiopian Institute of Agricultural Research, the effort of PARC staff as well as the District and kebele agricultural experts during the course of action warmly recognized.

\section{References}

Alemayehu Tassew (2017). Performance evaluation of upland rice varieties in south western areas of Ethiopia. Journal of Agricultural Research (03681157), 55(2).

CSA (Central Statistical Agency) (2018). Agricultural Sample Survey, Vol 1. Report on Area and Production of major crops, Meher season. Statistical Bulletin 586. Addis Ababa, Ethiopia.

Dawit Alemu, Agajie Tesfaye, Abebaw Assaye, Degu Addis, Tilahun Tadesse and Thompson J (2018). A historical analysis of Rice commercialization in Ethiopia: The case of the Fogera plain. A PRA working paper 18, Future Agricultures Consortium.

EIAR (Ethiopian Institute of Agricultural Research) (2016). Cereal crop production and management packages manual. Amharic version, Addis Ababa, Ethiopia.

Hailegebrial Kinfe, Yiergalem Tsehaye, Alem Redda, Redae Welegebriel, Desalegn Yalew and Welegerima Gebrelibanos. (2017). Yield and yield related performance of upland Rice genotypes in Tselemti district, North Ethiopia, 2015. J Rice Res 5: 187. DOI: http://dx.doi.org/10.4172/2375-4338.1000187.

Hailemariam Solomon (2016). Roles of rice FRGS in technology dissemination in Benishangul Gumuz region. Journal of Agricultural Research and Development. Vol. 6(3). pp. 070-074. DOI: http://dx.doi.org/10.18685/EJARD(6)3_EJARD-16-014

Mekonnen Bekele (2017). Agricultural Water Management and Smallholder Rice Production in Ethiopia. EDRI Research Report 30, Addis Ababa, Ethiopian Development Research Institute.

MoARD (Ministry of Agriculture and Rural Development) (2010). National Rice Research and Development Strategy of Ethiopia. The Federal Democratic Republic of Ethiopia, Ministry of Agriculture and Rural Development, Addis Ababa, Ethiopia. 48pp.

NBE (National Bank of Ethiopia) (2018). Annual Report. Addis Ababa, Ethiopia.

PDoA (Pawe District Office of Agricultural) (2018). Summary of Agricultural activity achievements report.

Samui, S.K., Maitra, S., Roy, D.K. Mondal, A.K. and Saha, D (2000). Evaluation on front line demonstration on groundnut (Arachis hypogea L.). J. Indian Soc. Coastal Agric. Res., 18: 180-183

Semagn Asredie, Walter De Jong, Keith Perry, Donald Halseth, Fentahun Mengistu (2017). Participatory Variety Selection: A Tool to Understand Farmers' Potato Variety Selection Criteria. Open Agriculture, 2(1), pp. 453463. DOI: https://doi.org/10.1515/opag-2017-0049.

Tamrat Belayneh and Jembr Tekle (2017). Review on adoption, trend, potential, and constraints of rice production to livelihood in Ethiopia. Int. J. Res - Granthaalayah, 5(6), 644-658. DOI: https://doi.org/10.5281/zenodo.824116. 
Teshome Negussie and Dawit Alemu (2011). An Overview of the National Rice Research and Development Strategy and its Implementation. FRG II project. Empowering Farmers' Innovation Series No. 2. pp. 1-16.

Wubale Tefera, Zinaw Dilnesaw, Kidane T/Michael, Abiwa Adane and Ashebir Getie (2019). Performance Evaluation of Six Rice (Oryza sativa L.) Varieties at Beles Sugar Development Project, Ethiopia. Int. J. Adv. Res. Biol. Sci. 6(2): 121-128. DOI: http://dx.doi.org/10.22192/ijarbs.2019.06.02.015.

Yalamalle, VR, and B. S. Tomar (2019). Effect of scape regulation on seed yield and quality in onion (Allium cepa)." Indian Journal of Agricultural Sciences 89.1:56-9. 